\title{
$\mathrm{SCIDOC}$ \\ Publishers
}

International Journal of Dairy Processing \& Research (IJDPR)

\section{Testing of Commercial Milk Production Technology Using A Combination of High Temperature Short Time and Pulsed Electric Field}

\author{
Research Article
}

Hadi A*, Widjanarko SB, Kusnadi J

Agricultural Engineering, Agricultural Technology Faculty, Brawijaya University Jl, Veteran Malang 65145, Indonesia.

Abstract

The development of milk processing technology has grown excessively, and it contains advantage and disadvantage. This study used mixed between PEF (Pulsed Electric Field) and High Temperature Short Time (HTST) to produce milk processed product which is effective and efficient in killing milk microorganism without changing its color, scent, and nutrient content of processed product, therefore producing commercial sterile milk product in accord with milk Indonesian National Standard (SNI). The method used was Milk Sterilization with HTST followed by PEF and PEF followed by HTST. Milk quality test result has already in accord with SNI, with protein content $4.3 \%$, fat content $5.3 \%$, dry ingredients without fat content $10.42 \%$, Total Plate Count (TPC) is $7.8 \times 10^{5} \mathrm{cfu} / \mathrm{ml}$. Based on HTST followed by PEF testing, fat content is $7.47 \%$ and protein content is $4.98 \%$, while for fresh milk testing, fat content is $7.43 \%$ and protein content is $4.16 \%$. TPC analysis result for method Sterilization HTST followed by PEF in $145^{\circ} \mathrm{C}$ for 5 second is $0 \mathrm{cfu} / \mathrm{ml}$. PEF followed by HTST for $145^{\circ} \mathrm{C}$ for 5 second was $15 \mathrm{cfu} / \mathrm{ml}$. The most approaching method accordance with Indonesian standard was sterilization combined with HTST followed by PEF with TPC result of $0 \mathrm{cfu} / \mathrm{ml}$. Therefore, this study was expected to be helping community in processing milk using fast and appropriate method. Milk processed product should also have a good content, not contaminated by pathogen and in accord with SNI.

Keywords: Sterilization; PEF (Pulsed Electric Field); TPC (Total Plate Count)

\section{Introduction}

The technology development has initiated larger milk demand. Milk processing technology in Small Medium Industry (SMI) had largely used conventional thermal pasteurization process (hightemperature, short-time; HTST). However, this method in varying degrees can affect the organoleptic and nutritional properties [4], such as dissolved of mineral, calcium and phosphorus also the damage of whey protein. In line with the increasing consumer demand of fresh milk has given rise to the development of non-thermal food preservation processes including pulsed electric field, high pressure, electric or magnetic fields, antimicrobial chemicals, lytic enzymes, as well as pulsed electric field $[5,10]$.

This study will examine the combined method between HTST and PEF in fresh milk production. PEF is one method of nonthermal food processing by using high intensity electric shock. PEF is applied to the liquid material. The process is short between one micro second to a millisecond with a short pulse [9].
Meanwhile, pulsed technology with high volt would only reduce bacteria about $85 \%$ and milk shelf life reaching 7 days [1]. Since PEF technology is still not optimum in killing bacteria therefore development was needed by combining PEF device and sterilization high temperature short time technology. It was expected that this study would obtain an effective and efficient milk sterilization device to kill milk microorganism without changing its color, scent and nutrient content of processed product, thus producing commercial sterile product in according with milk Indonesian Standard.

\section{Materials and Methods}

The fresh milk as the raw material was obtained from Milk Cooperative DAU in Malang Regency Indonesia.

\section{High Volt Generator}

A pulse generator is made up of a high voltage power supply,

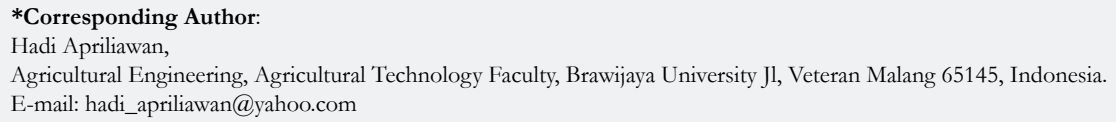

Citation: Hadi A, Widjanarko SB, Kusnadi J (2016) Testing of Commercial Milk Production Technology Using A Combination of High Temperature Short Time And Pulsed Electric Field. Int J Dairy Process Res. 3(1), 29-34. doi: http://dx.doi.org/10.19070/2379-1578-160009

Copyright: Hadi $\mathbf{A}^{\circ}$ 2016. This is an open-access article distributed under the terms of the Creative Commons Attribution License, which permits unrestricted use, distribution and reproduction in any medium, provided the original author and source are credited. 
thermocouple, capacitors, inductors, rectifying circuits and discharge switches and is capable of producing various types of wave shapes such as square or exponential. This tool is made for stainless steel food grade 316

\section{Tools and Materials for Sterilization Machine}

a. Tools used for sterilization machine would be hammer, thermocouple, tongs, screwdriver, ruler, electric weld, drill machine, meter gauge, and grinder

b. Materials used for sterilization machine would be $2 \mathrm{~mm}$ and $3 \mathrm{~mm}$ mica, stainless pump, stainless steel food grade 316 plate, PVC glue, Silicon, 0.5 inch pipe, faucet

c. Specification $=$ machine capacity: 50 liters (dimension: 260x125x270cm, type/material Stainless Steel Food Grade 316, Electric: 220 volt, Power: 2000 watt, Temperature: $135-155^{\circ} \mathrm{C}$ )

\section{Tools and Materials for Sterilization Machine Testing}

a. Testing tools $=$ voltmeter to measure low voltage, sela bola to measure high voltage, thermocouple for measuring temperature, thermo control to display material's temperature, and measuring cup to measure material's volume

b. Testing for amount of microorganism Materials used for TPC analysis consist of PCA medium, tools being used in this testing consist of umbrella paper, sterile gauze, distillate water, alcohol $70 \%$, autoclave, Erlenmeyer, goblet cup, stirrer, electric stove, thermometer, electric sterilization unit, incubator, Bunsen burner, bulb flask, vortex, water bath, volume pipette, Petri dish, colony counter

\section{Methods}

This study was carried in two phase. Phase I: Milk Sterilization with High Temperature Short Time followed by Pulsed Electric Field (PEF); Phase II: PEF followed by Milk Sterilization High Temperature Short Time. Both phase used steepest ascent with two treatment factors that were sterilization temperature and milk contact time with in tools, while observed response was TPC (Total Plate Count).

Furthermore, this study consisted of 9 treatments following Steepest Ascent Method design. The range of experiment between temperature of sterilization and contact time was given in Table 1. The first order or linear order utilization in study design was due to its improvement until there was no longer response improvement. The observation was conducted between variables and response thus improvement due to reduction would use second order or quadratic.

Table 1. Study Design to Build First Order Function Model

\begin{tabular}{|c|c|c|}
\hline Temperature of Sterilization $\left({ }^{\circ} \mathrm{C}\right)$ & Contact time (second) & TPC Responses $(\mathrm{cfu} / \mathrm{ml})$ \\
\hline 135 & 1 & \\
\hline 135 & 9 & \\
\hline 155 & 5 & \\
\hline 155 & 5 & \\
\hline 145 & 5 & \\
\hline 145 & 5 & \\
\hline 145 & 5 & \\
\hline 145 & 5 & \\
\hline 145 & & \\
\hline
\end{tabular}

Table 2. Characteristic of Fresh Milk (Raw Material)

\begin{tabular}{|c|c|c|}
\hline Parameter & Analysis Results & SNI $^{*}$ \\
\hline Color, smell, taste and viscosity & No changes & No changes \\
\hline Dirt and foreign matter & Negative & Negative \\
\hline protein content & $4.30 \%$ & Of at least $2.8 \%$ \\
\hline fat & $5.30 \%$ & Of at least $3.0 \%$ \\
\hline degrees Acid & $6.22^{\circ} \mathrm{SH}$ & $6-7.5^{\circ} \mathrm{SH}$ \\
\hline Density at a temperature of $27.5^{\circ} \mathrm{C}$ & 1.026 & Of at least 1.0270 \\
\hline Nonfat dry matter content contamination & $10.42 \%$ & Of at least $7.8 \%$ \\
\hline $\begin{array}{l}\text { contamination } \\
\text { hazardous metals } \\
\text { 1. Timbale }(\mathrm{Pb}) \\
\text { 2. Mercury }(\mathrm{Hg}) \\
\text { 3. Arsen }(\mathrm{As}) \\
\text { 4. Zinc }(\mathrm{Zn})\end{array}$ & $\begin{array}{c}\text { 1. }<0.1 \mathrm{ppm} \\
\text { 2. }<0.001 \mathrm{ppm} \\
\text { 3. }<0.001 \mathrm{ppm} \\
\text { 4. } 3.9 \mathrm{ppm}\end{array}$ & $\begin{array}{l}\text { 1. Maximum } 0.3 \mathrm{ppm} \\
\text { 2. Maximum } 0.5 \mathrm{ppm} \\
\text { 3. Maximum } 0.5 \mathrm{ppm} \\
\text { 4. Maximum } 0.5 \mathrm{ppm}\end{array}$ \\
\hline Total Plate Count & $7.8 \times 10^{5} \mathrm{cfu} / \mathrm{ml}$ & Maximum $1 \times 10^{6} \mathrm{cfu} / \mathrm{ml}$ \\
\hline Coliforms & $11 / \mathrm{ml}$ & Maximum $20 / \mathrm{ml}$ \\
\hline Salmonella sp & Negative & Negative \\
\hline Staphylococcus aureus & $0 \mathrm{cfu} / \mathrm{ml}$ & Maximum $1 \times 10^{2} / \mathrm{ml}$ \\
\hline
\end{tabular}

*Indonesian Standard (SNI 3141.1:2011) 
Figure.1 . Flow chart of this Study.

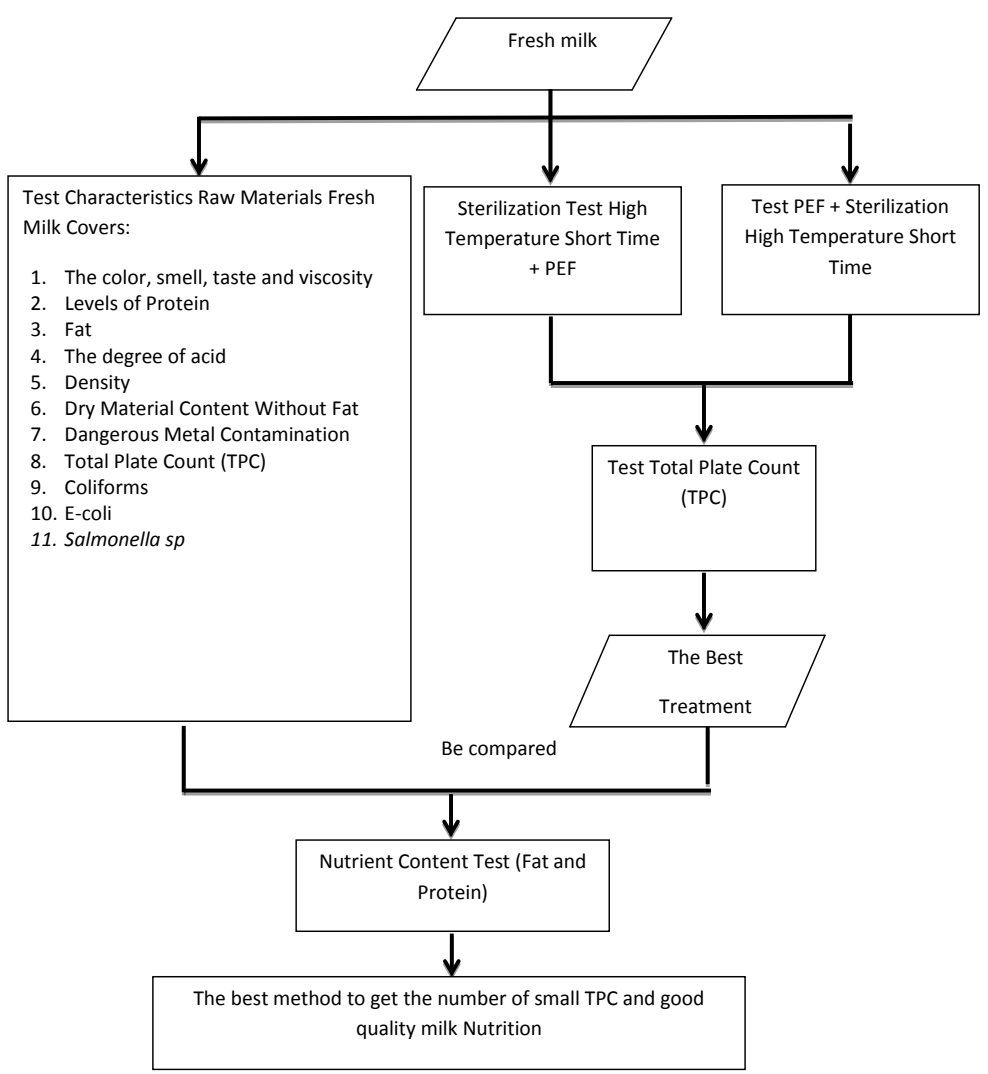

\section{Results and Discussions}

\section{Raw Materials Characterization}

Analyzed parameter in milk raw material is its fresh milk quality. Material analysis produced from all parameter showed that fresh milk being tested had value in accord with Indonesian Standard. Idris (1992) suggest that if there is chemical, physical or organoleptic change, it means that milk has been damaged. Analysis for milk specific weight result $1.026 \mathrm{~g} / \mathrm{ml}$ while according to SNI minimum specific weight of milk should be $1.027 \mathrm{~g} / \mathrm{ml}$ which means it is smaller than SNI. On the other hand, it is suggested that specific weight of milk would vary between $1.026 \mathrm{~g} / \mathrm{ml}$ and $1.032 \mathrm{~g} / \mathrm{ml}$. this variation was due to the difference in fat content, lactose, protein and minerals content [3]. The data of analysis result could be seen in Table 2 .

In zinc $(\mathrm{Zn})$ optimum operation parameter in which according to analysis result in $3.9 \mathrm{ppm}$ and according to Indonesian Standard (SNI 1998) maximum value of $0.5 \mathrm{ppm}$, our milk is way above it. Furthermore, based on the Indonesia National Agency of Drug and Food Control (BPOM) the maximum limit of Zn metal contamination in fresh milk was $40 \mathrm{ppm}$.

Steepest Ascent method was used as preliminary assessment concerning condition system. It was also used for novel study and which had no preliminary study that could be used as reference [7]. While the best treatment was used to determined central point for study design that is best result showed sterilization time using high temperature short time followed by PEF for 5 second with $145^{\circ} \mathrm{C}$. This central point $\left(5\right.$ second and $\left.145^{\circ} \mathrm{C}\right)$ would be increase and reduce for 5 second interval from central point for contact time treatment and $10^{\circ} \mathrm{C}$ interval for temperature treatment thus would obtain treatment as in study design. In study design, best treatment was in 5 second contact time with $145^{\circ} \mathrm{C}$ with 5 repetitions. Observation repetition in central point was meant to determine error.

\section{Result of TPC (Total Plate Count) Reduction in Milk Steri- lization Process of High Temperature Short Time + PEF}

The above graph showed best response was in $145^{\circ} \mathrm{C}$ and $5 \mathrm{sec}-$ ond contact time with TPC $0 \mathrm{cfu} / \mathrm{ml}$. Study conducted by Saleh (2004) using Two Stage (UHT) method with $135-155^{\circ} \mathrm{C}$ temperature for $2-5$ second could kill pathogenic and non-pathogenic bacteria. According to SNI (2000), maximum amount of TPC which is consumable is up to $<10 \mathrm{cfu} / \mathrm{ml}$ and this study showed TPC result in $0 \mathrm{cfu} / \mathrm{ml}$ thus it is highly consumable.

Furthermore, the maximum value determination from sterilization using High Temperature Short Time + PEF would be tested using steepest ascent method. Graphical presentation of steepest ascent treatment in sterilization using High Temperature Short Time + PEF is in Figure 3.

Contact time and temperature would determine TPC reduction value. Result from maximum steepest ascent method lies in basis $+2 \Delta$ that is $0 \mathrm{cfu} / \mathrm{ml}$. Regression value of $\mathrm{R} 2$ obtained from steepest ascent graphic is 0.9997 which means that its model fitness value is good. Study conducted by Junaidi (2014), R square $\left(\mathrm{R}^{2}\right)$ was often called as determination coefficient, which measuring fitness of regression equation, that is giving proportion or percentage in total variation within dependent variable explained by independent variable. $\mathrm{R}^{2}$ value was between $0-1$, and model fit- 
Figure 2. Graph showed effect of contact time and temperature toward TPC in sterilization using High Temperature Short Time + PEF

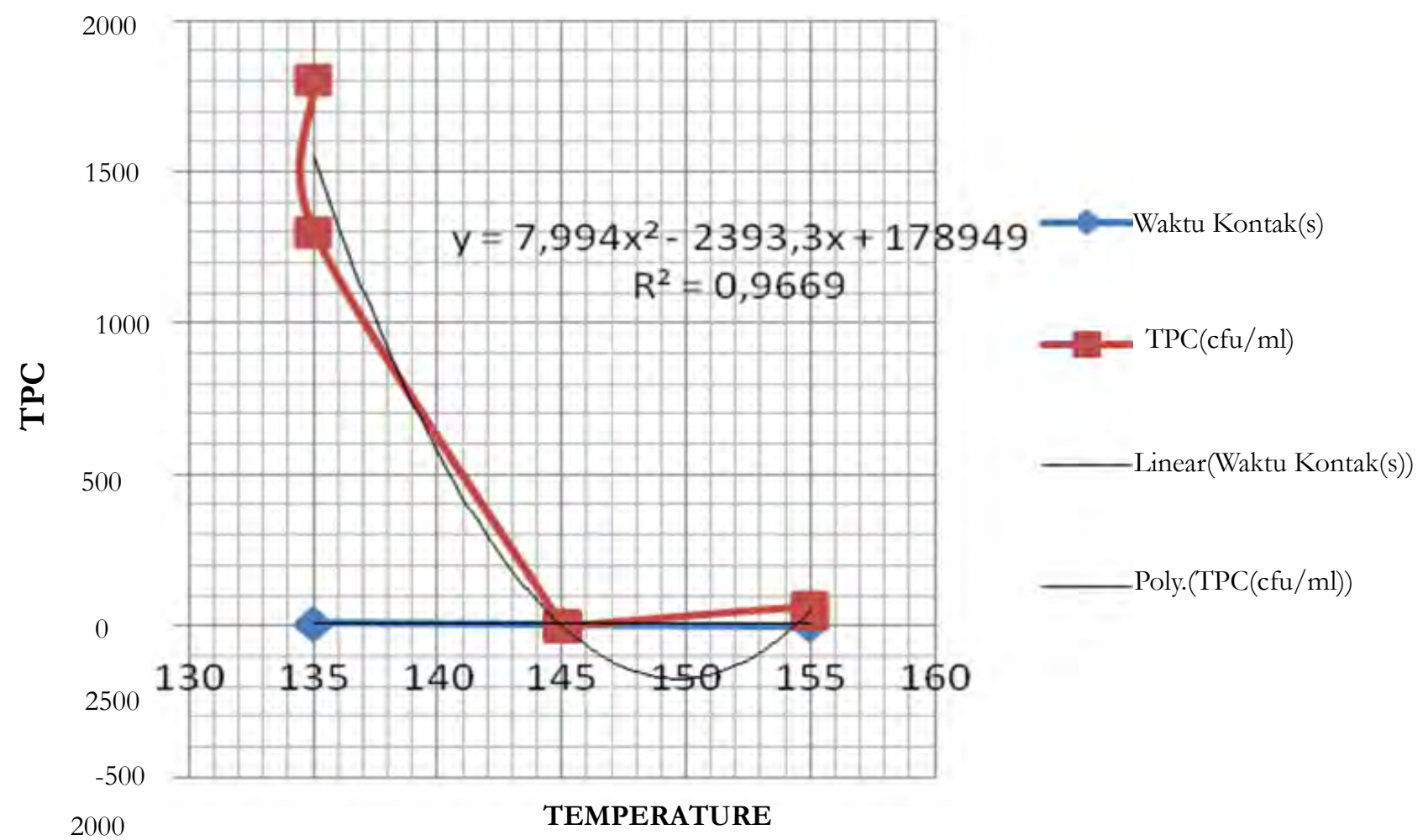

Figure 3. Graph showed steepest ascent of sterilization using High Temperature Short Time + PEF

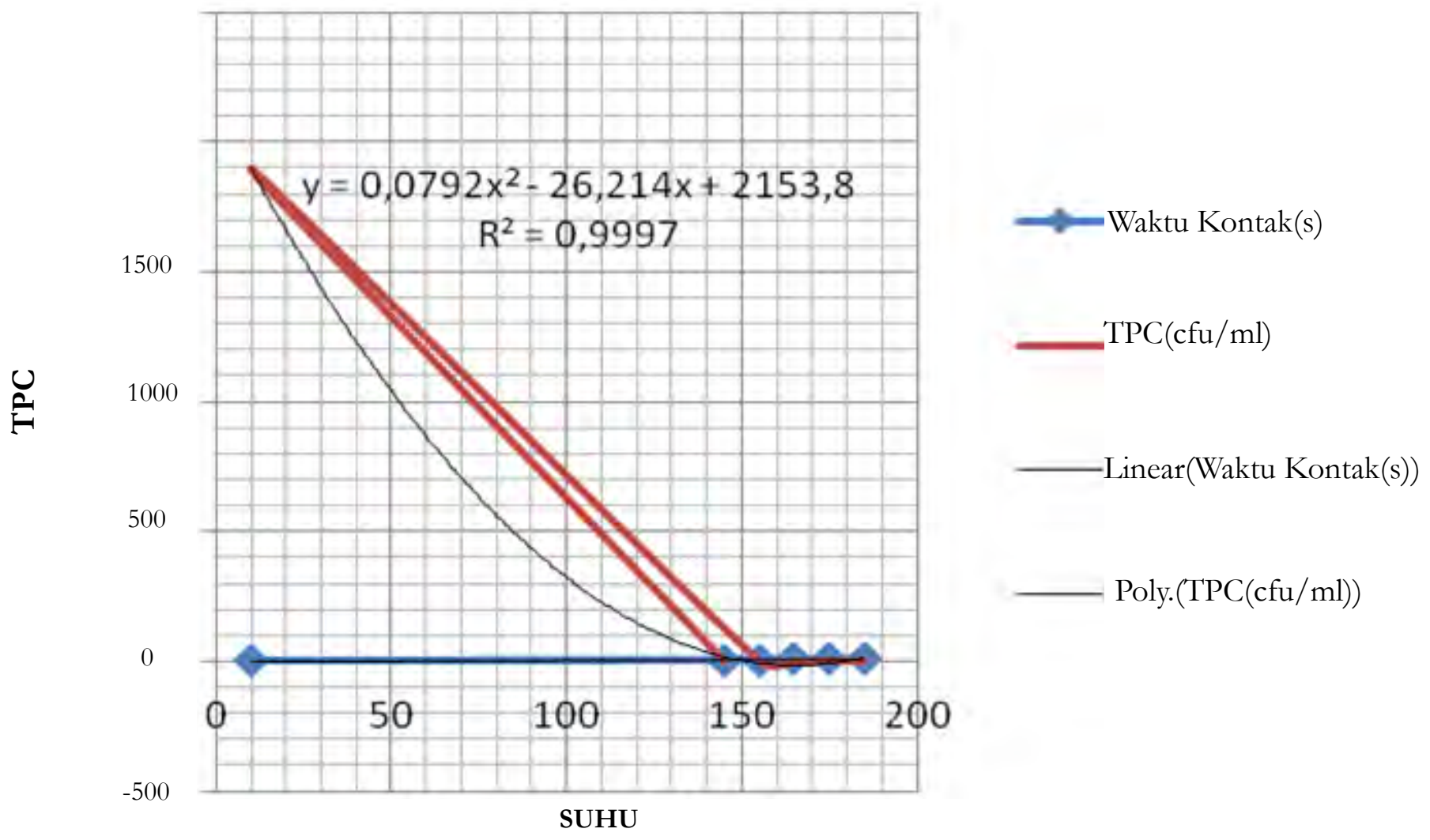

ness could be said better if $\mathrm{R}^{2}$ is approaching 1

Result in TPC (Total Plate Count) reduction in process of milk sterilization PEF + High Temperature Short Time

In the figure above, best response is in $145^{\circ} \mathrm{C}$ with contact time
5 second which give TPC $15 \mathrm{cfu} / \mathrm{ml}$. This is in accord with study conducted by Saleh (2004) using Two Stage (UHT) with $135-155^{\circ} \mathrm{C}$ for $2-5$ second which could kill pathogenic and nonpathogenic bacteria. According to SNI (2000), maximum value of TPC consumable is $<10 \mathrm{cfu} / \mathrm{ml}$ and according to this study, its TPC value is still on the benchmark value of SNI. Furthermore, the graphical presentation of steepest ascent method for PEF + 
Figure 4. Graph for effect of contact time and temperature toward amount of TPC in process PEF + Sterilization High Temperature Short Time

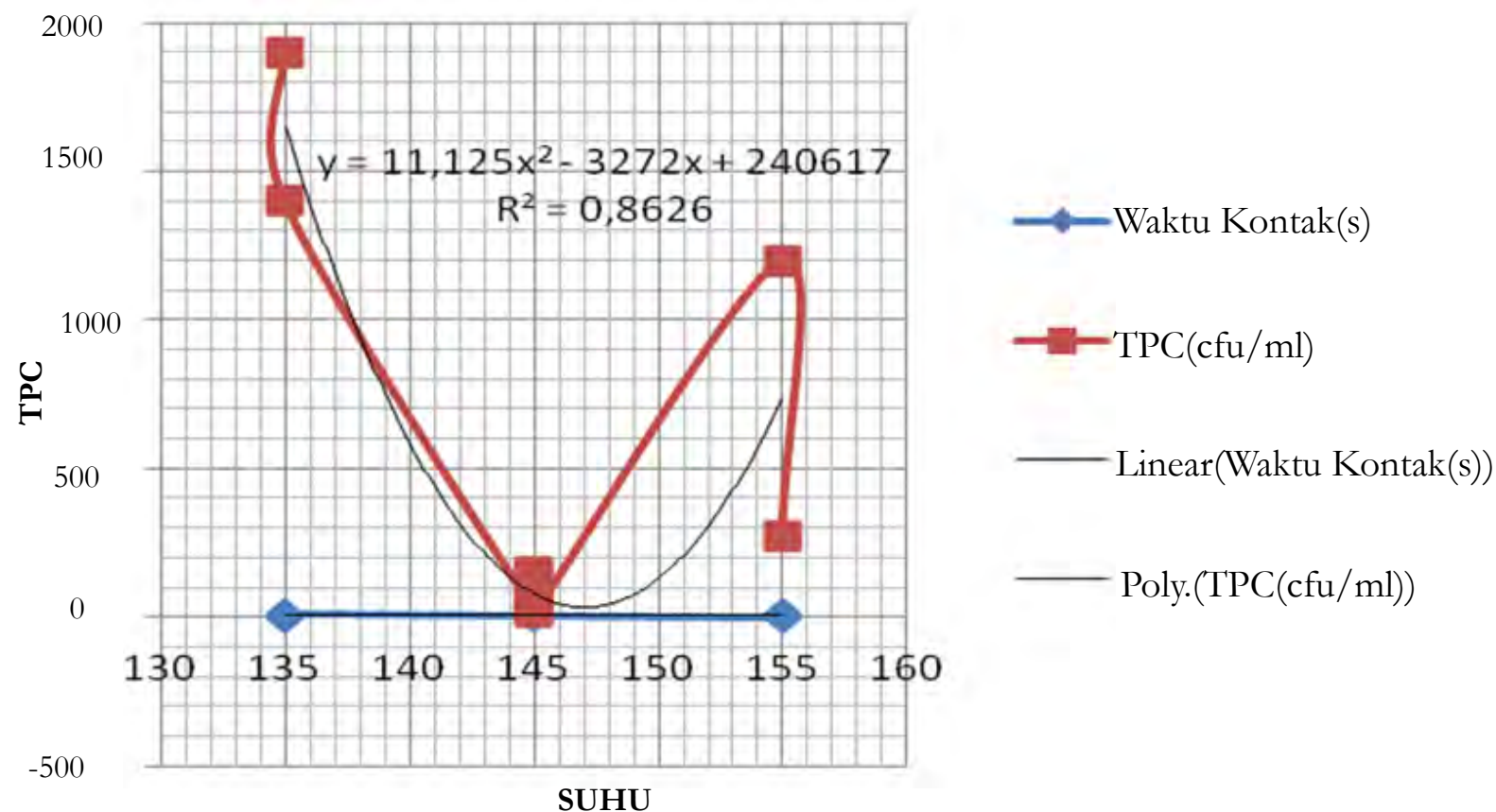

Figure 5. Graph of steepest ascent for treatment PEF + Sterilization High Temperature Short Time

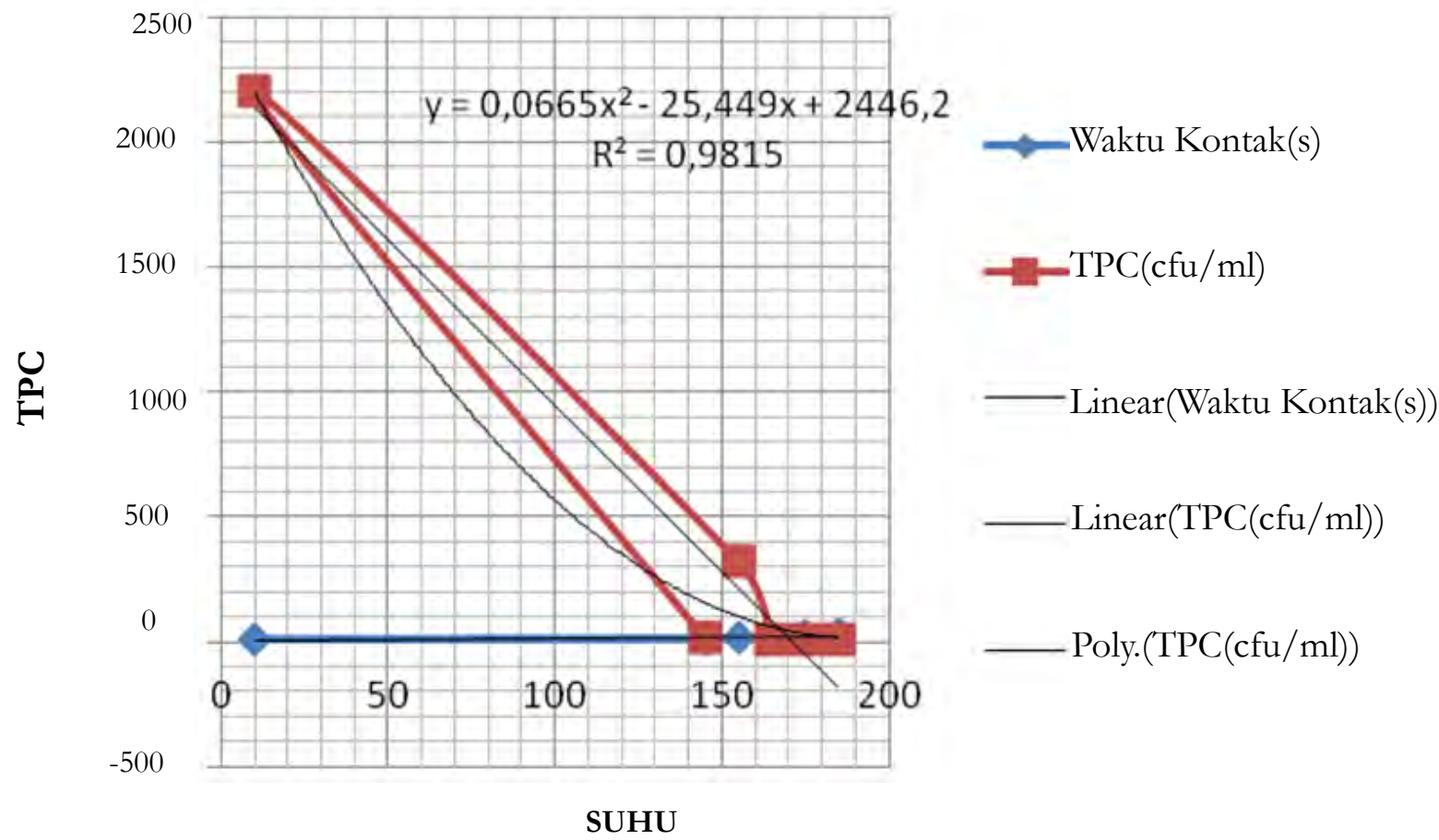

Sterilization High Temperature Short Time could be seen from Figure 5 below:

Contact time and temperature would determine amount of TPC reduction. Maximum result obtained from steepest ascent method is in basis $+2 \Delta$ that is $5 \mathrm{cfu} / \mathrm{ml}$. Based on both method, that is sterilization High Temperature Short Time followed by PFE and PFE followed by Sterilization High Temperature Short Time, the one better would be sterilization with High Temperature Short Time followed by PEF. Sterilization High Temperature Short
Time + PEF could reduce TPC value up to $0 \mathrm{cfe} / \mathrm{ml}$. While PEF followed by HTST would only reduce TPC up to $15 \mathrm{cfu} / \mathrm{ml}$.

Sterilization High Temperature Short Time followed by PEF method was better method due to pulsed electric field treatment for material getting through high temperature pipe thus producing maximum result compared to normal material condition when passing pulsed electric field. Sterilization process with PEF would produce maximum result if material is in high temperature. It was also explained that pulsed electric field with hot pre-treatment 
would produce maximum result compared with those using non pre-treatment [6]. The reduction of TPC in milk also was affected by temperature and time [11]. If pasteurization only aim to kill pathogen bacteria, sterilization aim to kill all bacteria, either pathogen or non pathogen. Temperature used in this matter is higher from pasteurization which is about $104-140^{\circ} \mathrm{C}$ with very short time about $1-4$ seconds.

The Comparison of Nutrient Content in Milk using Best Treatment Sterilization High Temperature Short Time + PEF and Fresh Milk

Based on the result obtained from testing sterilization High Temperature Short Time followed by PEF method would obtain fat content $7.47 \%$ and protein content $4.98 \%$, while in fresh milk, its value is $7.43 \%$ and $4.16 \%$, respectively. Fat had increase $0.04 \%$ followed by protein increase up to $0.82 \%$. This increase was due to high temperature heating thus water content of milk would evaporate and total solid (fat and protein) in milk would increase. Based on SNI standard (1998) for milk, fat minimum value is 3\% and protein content minimum value is $2.8 \%$. Fat and protein in milk using sterilization High Temperature Short Time + PEF is still in accord with SNI value.

Protein content in milk had average value of $3.2 \%$ which consist of $2.7 \%$ casein and $0.5 \%$ albumin. It means that $26.5 \%$ of milk's dry material is protein. Albumin was found 5 gram per $\mathrm{kg}$ milk, in dissolved. In $64^{\circ} \mathrm{C}$, albumin would become solid [13]. Thus amount of protein would increase if there is heating process.

Milk fat would be in fat globular shape with diameter of 1-20 micron. About $98-99 \%$ milk fat is in triglyceride. Creaming ability was fat ascending to the milk's surface. In temperature over $100^{\circ} \mathrm{C}$, there will be thin film in milk and coagulation of casein and fat would occur. During heating, water content would evaporate and decrease. Thus fat content would become higher [14].

\section{Conclusion}

Testing using sterilization High Temperature Short Time + PEF method would produce better result in milk by using $145^{\circ} \mathrm{C}$ for 5 second to produce TPC $0 \mathrm{cfu} / \mathrm{ml}$, while for PEF + Sterilization
High Temperature Short Time in $145^{\circ} \mathrm{C}$ for 5 second would produce TPC $15 \mathrm{cfu} / \mathrm{ml}$. Furthermore, based on Indonesian Standard (SNI 200), sterilization High Temperature Short Time combined with PEF technology produced milk in accordance with the standards with TPC of $0 \mathrm{cfu} / \mathrm{ml}$.

\section{References}

[1]. Apriliawan H (2014) Laban Electric Tool Milk Pasteurization High Voltage Electric Shock (Pulsed Electric Field) Using Flyback Transformer. Thesis: Agriculture Technology Faculty of Brawijaya University.

[2]. Indonesia National Agency of Drug and Food Control (1989) Limit Metal Contamination in Food. BPOM No: 03725/B/SK/VII/89

[3]. Buckle KA, Edward RA, Fleet GH, Wooton M (1987) Food Science. Universitas Indonesia Press, Jakarta.

[4]. Calderon-Miranda ML, Barbosa-Canovas GV, Swanson BG (1999) Inactivation of Listeria innocua in skim milk by pulsed electric fields and nisin. Int J Food Microbiol 51(1): 19-30.

[5]. Castro AJ, Barbosa-Canovas GV, Swanson BG (1993) Microbial inactivation of foods by pulsed electric fields. Journal of Food Processing and Preservation 17(1): 47-73.

[6]. Eka N, Hawa LH, Susilo B (2011) Inactivation comparative study of Escherichia coli and changes in the Physical Properties of Fresh Cow Milk Pasteurization Using the method of heating and without heating with Shock Electric Field. J Agric Technol 12(1): 31-39.

[7]. Gaspersz V (1992) Applied Systems Analysis: Based Approach Industrial Engineering. Tarsito Publishing, Bandung.

[8]. Idris (1992) Milk Damage. Milk Damage. Thesis Faculty of Animal Husbandry. Brawijaya University

[9]. Quass DW (1997) Pulsed Electric Field Processing in the Food Industry. A Status report on Pulsed Electric Field. Electric Power Research Institute, Palo Alto, CA.CR-109742. 23-35.

[10]. Pothakamury UR, Barbosa-Canovas GV, Swanson BG (1993) Magneticfield inactivation of microorganisms and generation of biological changes. Food Technol 47: 85-93.

[11]. Saleh E (2004) Milk Processing Technology and Animal Product. Faculty of Agriculture. University of Northern Sumatra.

[12]. Indonesia National Agency of Drug and Food Control (2000) Limit of Microbial Contamination and Maximum Residue Limit in Foodstuffs of Animal Origin. SNI-0106366-2000. Hal 3-4.

[13]. Stephanie, Harmita, Umar Mansur (2008) The determination of Levels of docosahexaenoic acid (DHA) in Infants and Children Formula in Gas Chromatography. University of Indonesia, Jakarta.

[14]. The Laboratory of Food Animal Product Technology (2009) Dairy Technology. Faculty of Animal Science Padjajaran University, Bandung. 